\title{
塩酸水溶液中に和ける金属クロムの耐食性に及ぼす 合金添加元素の効果*
}

\author{
加藤 雅 敏** 榊 \\ 孝**
}

J. Japan Inst. Metals, Vol. 56, No. 1 (1992), pp. 74-80

Effect of Alloying Elements on Corrosion Behaviour of $\mathrm{Cr}$ in $\mathrm{HCl}$ Solutions*

Masatoshi Kato** and Takashi Sakaki**

The corrosion behaviour of chromium-base alloys in $\mathrm{HCl}$ solutions with a concentration of more than $10 \%$ was investigated by measurements of the polarization curves, the change in corrosion potential with time and the average corrosion rate in the temperature range between room temperature and the boiling point.

The corrosion resistance of chromium-base alloys was improved by adding noble metals such as palladium and ruthenium. From the immersion test it was shown that the chromium-base alloys containing more than 0.05 mass\% palladium and more than 0.2 mass\% ruthenium revealed high corrosion resistance. The addition of molybdenum also improved the corrosion resistance, but its effect was smaller than that of the additons of palladium and ruthenium, even if about $10 \%$ molybdenum was added to the alloys.

The additions of palladium and ruthenium to chromium increased the cathodic current, and decreased the anodic dissolution current as the $\mathrm{Cr}^{3+}$ or $\mathrm{Cr}^{2+}$ ion in the active state. Accordingly the corrosion potential of the alloys shifted to the noble direction and the alloys were easily passivated.

The effect of the palladium and ruthenium additions on the corrosion behaviour of chromium is therefore caused mainly by cathodic depolarization.

(Received July 26, 1991)

Keywords: corrosion, chromium, chromium based alloy, $\mathrm{HCl}$, electrochemical behaviour

\section{I．緒言}

金属 $\mathrm{Cr}$ は難加工性のため純金属としての使用が制限さ れてきたが，近年, 高純度化粉末製造技術や圧延法の改 良, あるいは新しい加工技術の開発により各種形状の加工 材が開発されるに至った(1)-(6).

か上うな金属 $\mathrm{Cr}$ の耐食性，耐高温腐食性に関しては不 明な点が多く, 著者らは, 一連の研究を高温ガス, 溶融塩 あるいは各種水溶液等の種々の環境で行ってきた

それによると金属 $\mathrm{Cr}$ は従来の低品位金属 $\mathrm{Cr}$ とは異な り有機酸等の還元性の酸に颃いても高い耐食性を有する ${ }^{(8)}$. また，一般的に $\mathrm{Cr}$ めっき等が激しく腐食されると言われ る塩酸あるいは硫酸中においても金属 $\mathrm{Cr}$ は，高い自己不 働態化能力を有し，低温低濃度の環境中であれば汪とんど 腐食を受けないことを明らかにした。しかしながら, 高温 あるいは高濃度の非酸化性酸環境になると, 高純度金属 Crであっても自己不働態化能力を失い水素発生を伴った 激しい全面腐食を受ける(9)-(11).

本研究は, 金属 $\mathrm{Cr}$ が全面腐食される高温高濃度の塩酸
水溶液環境において $\mathrm{Cr}$ の耐食性におよぼす合金添加元素 の効果, また, その機構について調查, 考察したものであ る.

\section{II. 実 験 方 法}

試料としては, Table 1 亿示すよらな純 $\mathrm{Cr}$ 板材拈よび $\mathrm{Pd}, \mathrm{Ru}, \mathrm{Mo}$ 等を種々添加した $\mathrm{Cr}$ 基合金を用いた。これ らの試料は, $\mathrm{Ar}$ 雰囲気炉による高周波溶解法によって作 製し，熱処理を行うことなく鋳造組織のまま所定の寸法に 切出した. また，比較材料として真空溶解鋳造後さらに圧 延処理を施した $\mathrm{Fe}-30 \mathrm{Cr}$ 合金ならびに市販の $\mathrm{Ti}$ 板(神戸 製鋼製 KS50)を用いた.

浸漬試験では主に $30 \mathrm{~mm} \times 20 \mathrm{~mm} \times t 3 \mathrm{~mm}$ の寸法の試 片を使用し，電気化学的測定には，樹脂シールドを施した $10 \mathrm{~mm} \times 10 \mathrm{~mm}$ の電極面積を有する電極を用いた.

溶液はすべて特級試薬を用いて調整した。

実験は大気開放系で行った。

$\mathrm{Cr}$ 基合金についてはすべてが固溶合金であるため，そ れら合金の腐食速度は組成值から密度を仮定し，浸漬前後

\footnotetext{
*1990年 5 月腐食防食'90に一部発表

** 東ソー(侏)化学研究所 (Chemical Research Laboratories, TOSHO Corp., Yamaguchi)
} 
Table 1 Chemical composition of specimens used. (mass\%)

\begin{tabular}{l|c|c|c|c|c|c|c|c|c|c|c|c|c|c|c|c}
\hline \hline Materials & $\mathrm{C}$ & $\mathrm{H}$ & $\mathrm{O}$ & $\mathrm{N}$ & $\mathrm{S}$ & $\mathrm{P}$ & $\mathrm{Si}$ & $\mathrm{Al}$ & $\mathrm{Pb}$ & $\mathrm{Cu}$ & $\mathrm{Cr}$ & $\mathrm{Fe}$ & $\mathrm{Ti}$ & $\mathrm{Pd}$ & $\mathrm{Ru}$ & $\mathrm{Mo}$ \\
\hline $99.73 \mathrm{Cr}$ & 0.012 & 0.0005 & 0.084 & 0.0048 & 0.0007 & 0.0017 & 0.0400 & 0.0050 & 0.0001 & 0.0011 & bal. & 0.1200 & - & - & - & - \\
\hline $\mathrm{Cr}-0.2 \mathrm{Pd}$ & 0.009 & - & 0.051 & 0.0033 & 0.0001 & - & - & - & - & - & bal. & - & - & 0.22 & - & - \\
\hline $\mathrm{Cr}-0.4 \mathrm{Pd}$ & 0.021 & - & 0.034 & 0.0027 & 0.0001 & - & - & - & - & - & bal. & - & - & 0.43 & - & - \\
\hline $\mathrm{Cr}-0.5 \mathrm{Ru}$ & 0.011 & - & 0.055 & 0.0039 & 0.0001 & - & - & - & - & - & bal. & - & - & - & 0.50 & - \\
\hline $\mathrm{Cr}-1.6 \mathrm{Ru}$ & 0.015 & - & 0.028 & 0.0034 & 0.0001 & - & - & - & - & - & bal. & - & - & - & 1.64 & - \\
\hline $\mathrm{Cr}-3 \mathrm{Ru}$ & 0.009 & - & 0.045 & 0.0035 & 0.0001 & - & - & - & - & - & bal. & - & - & - & 3.30 & - \\
\hline $\mathrm{Cr}-5 \mathrm{Mo}$ & 0.010 & - & 0.059 & 0.0041 & 0.0001 & - & - & - & - & - & bal. & - & - & - & - & 5.3 \\
\hline $\mathrm{Fe}-30 \mathrm{Cr}$ & 0.002 & - & - & 0.012 & 0.018 & - & - & 0.002 & - & - & 30.43 & bal. & - & - & - & - \\
\hline $\mathrm{Ti}$ & - & 0.0009 & 0.108 & 0.006 & - & - & - & - & - & - & - & 0.054 & bal. & - & - & - \\
\hline
\end{tabular}

の重量変化より求めた.

金属 $\mathrm{Cr}$ の不働態皮膜の安定性を評価する方法としては $0 \mathrm{~V}$ (vs SCE) 以上の電位で定電位電解を実施し, 電解後, 溶液中の $\mathrm{Cr}$ 量をフレームレス原子吸光法により分析定量 することにより行った。

合金添加元素を選定するための 1 次評価として, 10 $\mathrm{mm} \times 10 \mathrm{~mm}$ の電極面積を有する金属 $\mathrm{Cr}$ と同一電極面積 を有する他の有望視される各種金属とのカップリング電位 を測定し，その際の貴側への電位シフトの大きいものを合 金添加候補材料とした.

各種合金に対する電気化学的な評価として，腐食電位の 経時変化执よび分極曲線を測定した。アノードおよびカソ 一ド分極曲線は, SCE を参照極として用い, 電位走査法 により測定した。電位を $1 \times 10^{-3} \mathrm{~V} \cdot \mathrm{s}^{-1}$ の掃引速度で貴 側および卑側へ印加し, 得られた分極曲線より不働態保持 電流ならびに活性溶解のピーク電流を実測した.

\section{III. 結果および考察}

\section{1. 合金添加元素の検討}

金属 $\mathrm{Cr}$ は，10\%以下の低濃度塩酸中に拈いてはほとん ど腐食しない。しかし，10\%以上の濃度では $\mathrm{Fe}-30 \mathrm{Cr}$ と 同様，高濃度塩酸中に扣いては激しく腐食する。このよう な腐食は前報(6)で示したよらに金属 $\mathrm{Cr}$ が不働態皮膜を保 持再生できず活性溶解するためである.

金属 $\mathrm{Cr}$ の上らな不働態化し易い金属では, その不働態 皮膜の安定性が耐食性の良否を左右する。そこで，不働態 皮膜が安定に保持し得る $0 \mathrm{~V}$ (vs SCE) 以上の貴な電位に 扣いて定電位電解を行い不働態皮膜の溶出量を測定した.

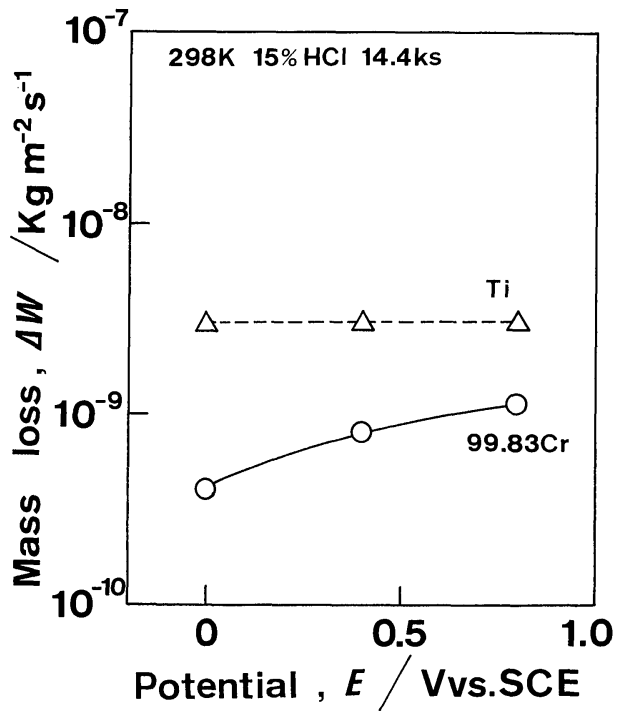

Fig. 1 Relationship between the mass loss and potential in $\mathrm{HCl}$ solution. The weight loss was calculated from the amount of dissolved $\mathrm{Cr}^{3+}$ and $\mathrm{Ti}^{4+}$.

その結果を Fig. 1 に示す. 金属 Cr はTi に比べると塩酸 溶液中での不働態皮膜の溶出量が小さい。このことから不 働態皮膜が速やかに再生され安定に存在すれば塩酸中でも 十分な耐食性が維持されることが示唆される．金属 Crk 自己不働態化能力を付与するためには，何らかの外的作用 を加え，電位を活性領域より貴な状態に移行させることが 必要である. Table 2 は, 活性溶解している金属 Cr に, 金属 $\mathrm{Cr}$ と同一電極面積を有する各種金属を接触させた時 の混成電位を示す.表からも明らかなように $\mathrm{Pt}, \mathrm{Pd}$ 执よ

Table 2 Galvanic potential between $\mathrm{Cr}$ and various metals in $\mathrm{HCl}$ solution. The ratio of surface area of $\mathrm{Cr}$ to the other metal was $1: 1$.

\begin{tabular}{c|c|c|c|c|c|c|c|c|c}
\hline \hline Material & 99.73 Cr Cast & $\mathrm{Cr}-\mathrm{Pt}$ & $\mathrm{Cr}-\mathrm{Pd}$ & $\mathrm{Cr}-\mathrm{Ru}$ & $\mathrm{Cr}-\mathrm{Mo}$ & $\mathrm{Cr}-\mathrm{Ag}$ & $\mathrm{Cr}-\mathrm{Nb}$ & $\mathrm{Cr}-\mathrm{Cu}$ & $\mathrm{Cr}-\mathrm{In}$ \\
\hline Potential (V vs. SCE) & -0.63 & -0.43 & -0.46 & -0.52 & -0.59 & -0.62 & -0.63 & -0.62 & -0.70 \\
\hline
\end{tabular}


び Ru は電位を貴な方向へ移行させた。すなおち，これら の元素は他の金属元素に比べ高い電位シフト能力を有し金 属 $\mathrm{Cr}$ の不働態化能力を高める作用がある.

以上の結果を基に $\mathrm{Ru}, \mathrm{Pd} の 2$ 元素を添加した $\mathrm{Cr}$ 基合 金を作製し，各種の耐食性評価ならびに電気化学的評価を 行った．また，Moについてもその電位シフト能力は小さ いが，一般にステンレス鋼に添加される基本元素として興 味深いところから基礎的評価に加光た.

\section{Cr-Pd 合金の腐食挙動}

$298 \mathrm{~K}$ で種々の濃度の塩酸水溶液中に抢ける $\mathrm{Cr}-\mathrm{Pd}$ 合 金の腐食速度を金属 Cr と比較して Fig. 2 亿示寸. Pd を $0.2 \%$ 添加した合金は金属 $\mathrm{Cr}$ が激しく腐食する $10 \%$ 以上 の濃度の塩酸水溶液中に打いても十分な耐食性を維持して いる。腐食速度に拈よぼす温度の影響を Fig. 3 亿示すが， $\mathrm{Cr}-\mathrm{Pd}$ 合金は金属 $\mathrm{Cr}$ に比べるとより高温まで耐食性を維 持することが出来る。しかし， Cr-0.2 Pd 合金あるいは $\mathrm{Cr}-0.4 \mathrm{Pd}$ 合金のいずれに扒いても $20 \%$ 以上の高濃度塩酸 あるいは $373 \mathrm{~K}$ 以上の高温域においては金属 $\mathrm{Cr}$ と同様に 水素発生を伴った活性溶解による激しい全面腐食を受け る.

ここで Pd 添加の効果を定量的に検討するため，合金中 の $\mathrm{Pd}$ の添加量を種々変化させた時の $323 \mathrm{~K} 10 \%$ 塩酸中 に和ける腐食速度を測定した．Fig. 4 亿は Ti 合金につい ての結果も併せて示している. Cr 合金は Ti 合金と同様, ある臨界濃度以上の $\mathrm{Pd}$ が添加されると腐食速度は急激に 減少する。しかし，Pd 添加による防食作用は同一ではな い. $\mathrm{Pd}$ を添加しない時の金属 $\mathrm{Cr}$ の腐食速度は Ti に比べ

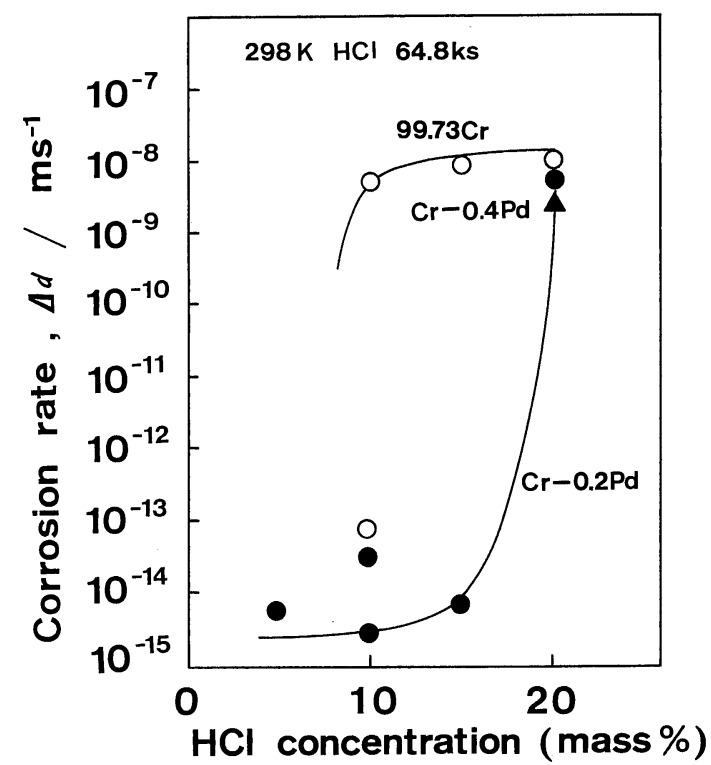

Fig. 2 Relationship between the corrosion rates and $\mathrm{HCl}$ concentration.
ると 100 倍以上の大きな值を示すのに対し，Pd が $0.05 \%$ 以上添加された合金に沶いては $\mathrm{Cr}$ の方が Ti に比べると 1/100以上の小さい腐食速度を示す．これらのことから， $\mathrm{Cr}$ 合金は Ti 合金に比べると $\mathrm{Pd}$ 添加による腐食速度低減 の効果が大きく，この環境に执いて，0.05\%程度の極微量 の $\mathrm{Pd}$ 添加でも金属 $\mathrm{Cr}$ の耐食性向上には十分な効果が得 られる。

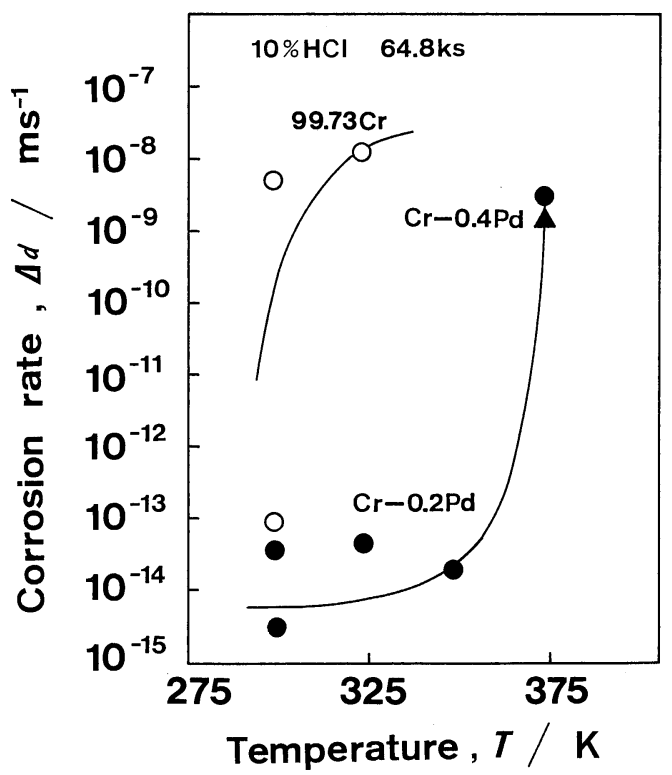

Fig. 3 Effect of temperature on the corrosion rates of $\mathrm{Cr}-\mathrm{Pd}$ alloys immersed in $\mathrm{HCl}$ solution.

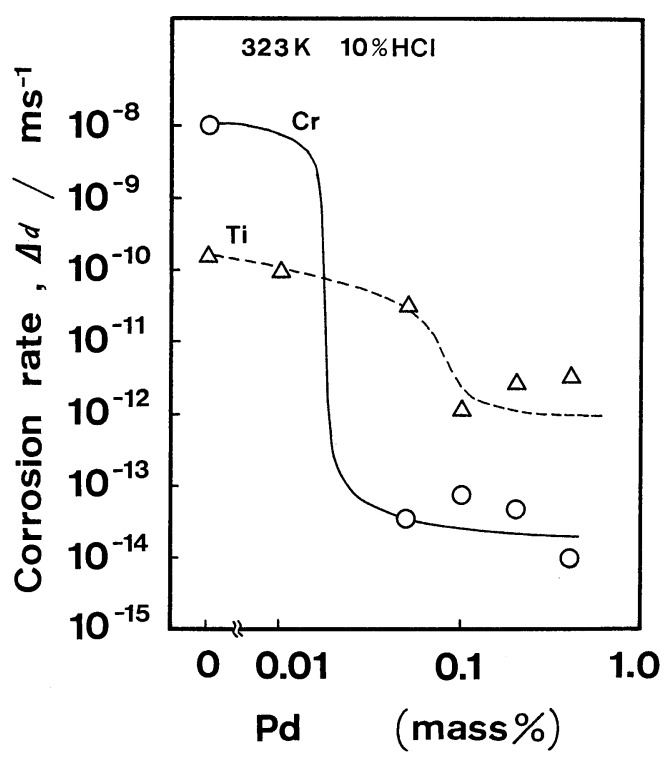

Fig. 4 Effect of $\mathrm{Pd}$ content on the corrosion rates of $\mathrm{Cr}-\mathrm{Pd}$ and $\mathrm{Ti}-\mathrm{Pd}$ alloys immersed in $\mathrm{HCl}$ solution. 


\section{Cr-Pd 合金の電気化学的挙動}

$\mathrm{Cr}-\mathrm{Pd}$ 合金は金属 $\mathrm{Cr}$ 亿比較すると種々の環境で高い耐 食性を保持するが，この高耐食性は，Fig. 5 の 298 K, $10 \%$ 塩酸水溶液中に打ける各種金属の腐食電位の経時変 化に見られるように，Cr-Pd 合金は長時間にわたり，金属 $\mathrm{Pd}$ と同様，安定でかつ貴な腐食電位を維持するためであ る.これに対し金属 $\mathrm{Cr}$ は短時間で電位が卑側に移行し， 活性溶解し再び不働態化することはない，そして，図中に 示した $\mathrm{Cr}-0.05 \mathrm{Pd}$ 合金の挙動からも明らかなよらに $\mathrm{Pd} の$ 添加量の少ないCr-Pd 合金は自然浸漬状態に扣いて浸漬 開始直後の初期の腐食電位が不安定であり， $-0.6 \mathrm{~V}$ 前後 の卑な電位にシフトすることがあるが，活性溶解反応を生 じても短時間で再び自己不働態化し貴な腐食電位に復帰し 再不働態化する.そしてこの後は長時間にわたり貴な不働 態領域の腐食電位を安定に保持する。この Cr-Pd 合金の 不働態皮膜の優れた再生能力が高い耐食性を維持する理由 の一つと考学られる。

次に塩酸中でのアノード分極曲線をFig. 6 亿示す．金 属 $\mathrm{Cr}$ は大きな活性溶解のピークを有しているが，速やか に不働態化しその保持電流も小さい。これに対し, $\mathrm{Cr}$ $0.2 \mathrm{Pd}$ 合金は, $\mathrm{Pd}$ の作用により活性溶解のピーク電流が $1 / 100$ 程度に減少し, 後に続く不働態化反応子速やかに起 こる. 不働態保持電流については金属 $\mathrm{Cr}$ と同程度の值で あり， $\mathrm{Pd}$ の作用は金属 $\mathrm{Cr}$ の不働態皮膜そのものを改質 してはいない.むしろ $0.2 \mathrm{~V}$ 付近に拁いては電流值の增加 している領域も見られ，見かけ上不働態の安定性は若干低 下する。 しかしながら，この電流は吸蔵水素の酸化による ものである。これはFig. 7 に示す掃引開始の電位を $-0.5 \mathrm{~V}$ と $0 \mathrm{~V}$ に変化させて測定した金属 Pdのアノード 分極曲線の相違からも分かる。 $-0.5 \mathrm{~V}$ から電位掃引を開 始し，カソード反応により十分な水素発生を行わせた金属 $\mathrm{Pd}$ はカソード領域で水素吸蔵反応を生じ，これにより吸

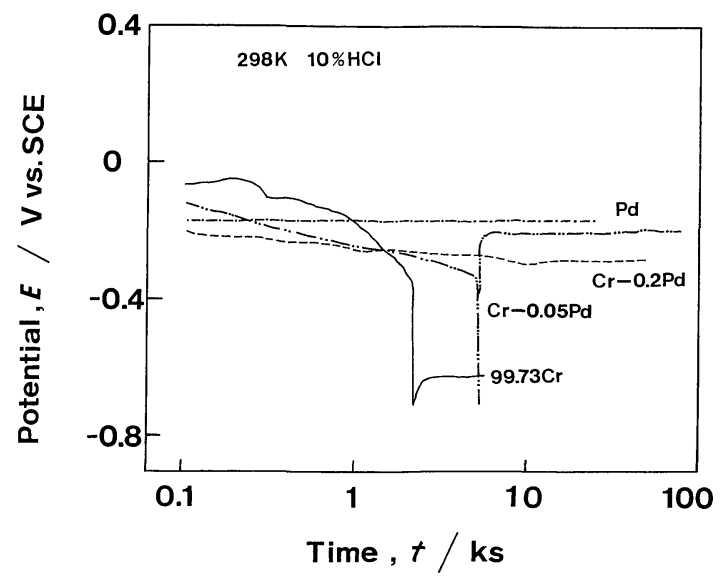

Fig. 5 Change in the corrosion potential with time in $\mathrm{HCl}$ solution.
蔵された水素が水素イオンに酸化され，0 V 以上の貴な電 位領域に执いてアノード電流を生じる。この反応により Cr-Pd 合金の見掛けの不働態保持電流が大きくなる.

次にカソード領域での Pd の効果は, 水素発生過電圧を 低下させ，カソード電流を増加させる．このため，見掛け

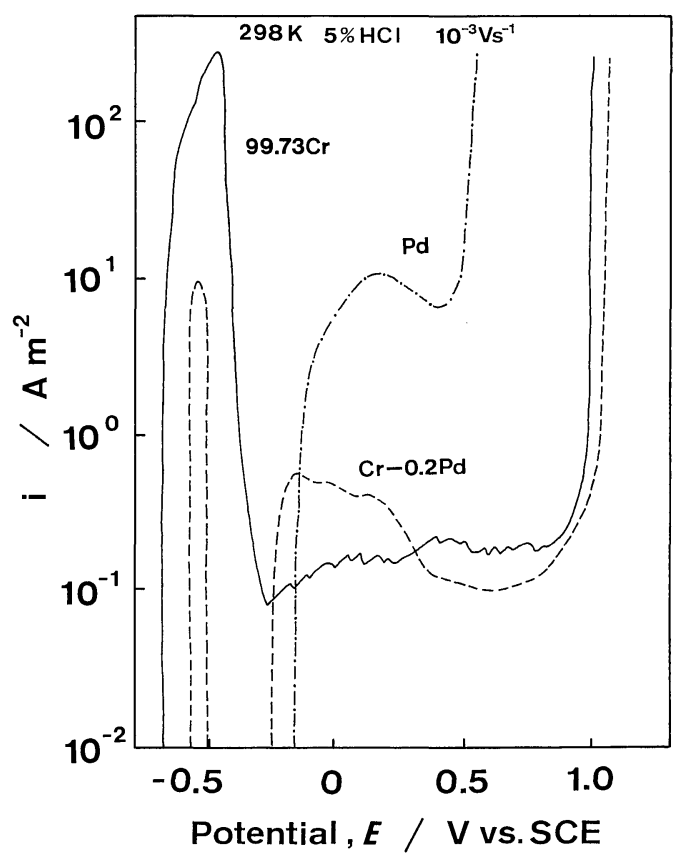

Fig. 6 Polarization curves of various metallic materials in $\mathrm{HCl}$ solution.

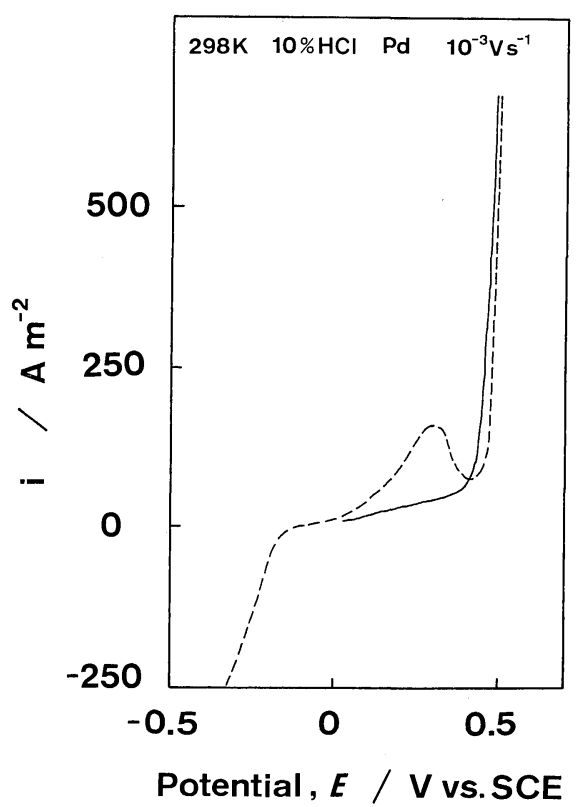

Fig. 7 Polarization curves of $\mathrm{Pd}$ in $\mathrm{HCl}$ solution. The starting potentials for the sweep were changed from

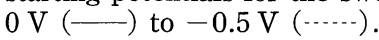


の活性溶解領域での電流值が下がるカソード復極剤として 作用している.

以上の上ら飞金属 $\mathrm{Cr}$ 飞添加される $\mathrm{Pd}$ の作用は, 主に カソード復極剤的役割を有し，電位を貴に移行させること により，不働態化能あるいは不働態皮膜の再生能力を高め ていると言える.

\section{Cr-Ru 合金の腐食挙動}

$\mathrm{Pd}$ の効果に続き, 次に $\mathrm{Ru}$ の効果について述べる. Fig. 8 は $10 \%$ 塩酸中に抢ける $\mathrm{Cr}-\mathrm{Ru}$ 合金の腐食速度であ る.

金属 $\mathrm{Cr}$ は本環境下で激しく腐食されるが， $\mathrm{Cr} に 0.5 \% \mathrm{Ru}$ を添加すると常温から $373 \mathrm{~K}$ までの広い温度範囲に扣い て全く腐食されなくなる．1.6\% Ru 合金では，さらに耐食 領域が高温側まで広がる. Fig. 3 亿示した Cr-0.4 Pd 合金 の耐塩酸性と $\mathrm{Cr}-0.5 \mathrm{Ru}$ 合金を比較すると, その耐食領域 は $\mathrm{Ru}$ 合金の方が高温度側ヘシフトし，金属 $\mathrm{Cr}$ の耐食性 改善効果は Ru の方が大きいと言える.

さらに $\mathrm{Ru}$ 添加の効果を明らかにするため $\mathrm{Ru}$ 添加量を 種々変化させた合金試料を作製し，10\%塩酸水溶液中に 扎ける浸漬腐食試験を行った。

Fig.9からも明らかなように，373 K に括いては0.5\% 以上の $\mathrm{Ru}$ 添加, $393 \mathrm{~K}$ に扬いては $1.2 \%$ 以上の $\mathrm{Ru}$ 添加に より著しく耐食性の向上がみられる。しかしながら，塩酸 濃度が15\%以上になると $393 \mathrm{~K}$ では Ru を添加しても， もはや耐食性改善を期待することはできないまた，373 $\mathrm{K}$ に扣いて塩酸濃度を種々変化させた際の $\mathrm{Cr}-1.6 \mathrm{Ru}$ 合 金は，塩酸濃度が $15 \%$ を越えると腐食速度の急激な上昇

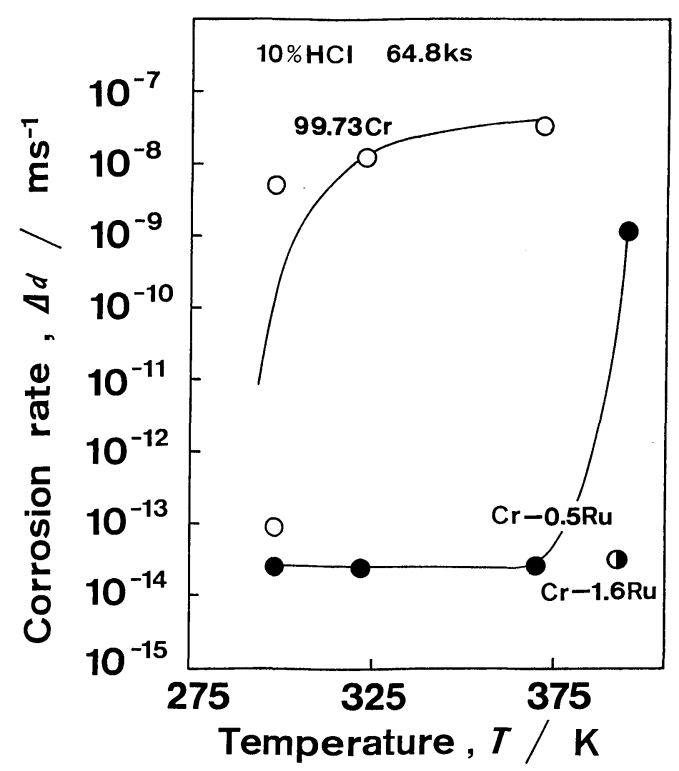

Fig. 8 Effect of temperature on the corrosion rates of $\mathrm{Cr}$-Pd alloys immersed in $\mathrm{HCl}$ solution.

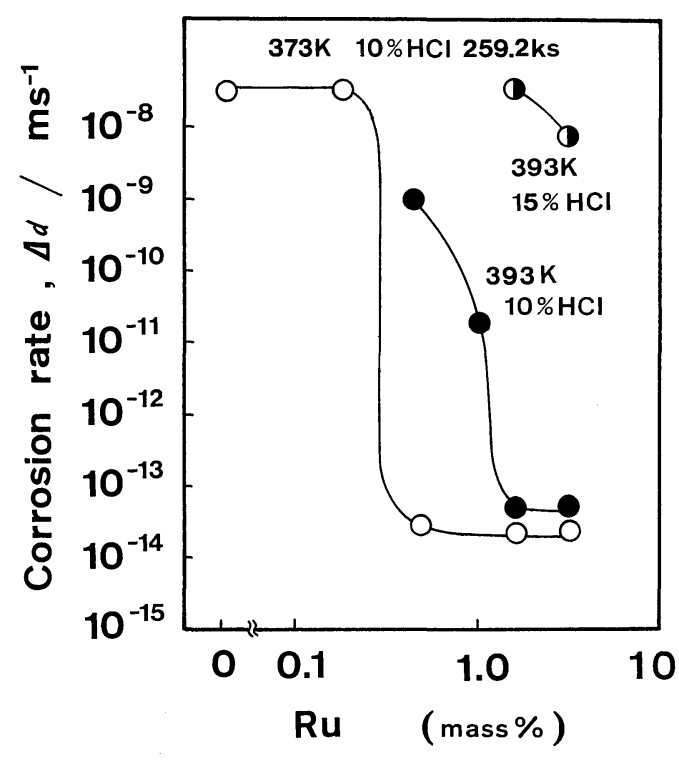

Fig. 9 Effect of Ru content on the corrosion rates of $\mathrm{Cr}-\mathrm{Ru}$ alloys immersed in $\mathrm{HCl}$ solution at various temperatures.

を生じることが分かる。このような高塩酸濃度領域では $\mathrm{Cr}_{2} \mathrm{O}_{3}$ 自身が化学溶解するといわれており, $\mathrm{Cr}$ ならびに $\mathrm{Cr}$ を基とする合金での耐食限界と位置付けることができ る.

\section{5. $\mathbf{C r - R u}$ 合金の電気化学的挙動}

まず初めに金属 $\mathrm{Cr}, \mathrm{Cr}-0.5 \mathrm{Ru}$ 合金拈よび金属 $\mathrm{Ru}$ の $10 \%$ 塩酸中に怙ける自然浸漬電位の経時変化曲線を Fig. 10 亿示す．金属 $\mathrm{Ru}$ の浸漬電位は $0.5 \mathrm{~V}$ 以上の貴な 電位を有する。このため, $\mathrm{Cr}-0.5 \mathrm{Ru}$ 合金は金属 $\mathrm{Cr}$ とは 異なり，比較的安定な $0.2 \mathrm{~V}$ 以上の貴な電位を示す.この $\mathrm{Cr}-0.5 \mathrm{Ru}$ 合金の值は Fig. 5 に示した Cr-Pd 合金系より

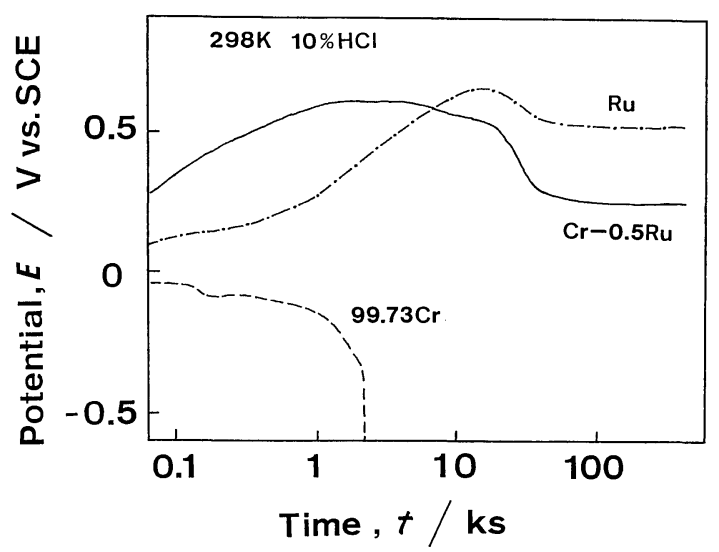

Fig. 10 Change in the corrosion potential with time in $\mathrm{HCl}$ solution. 


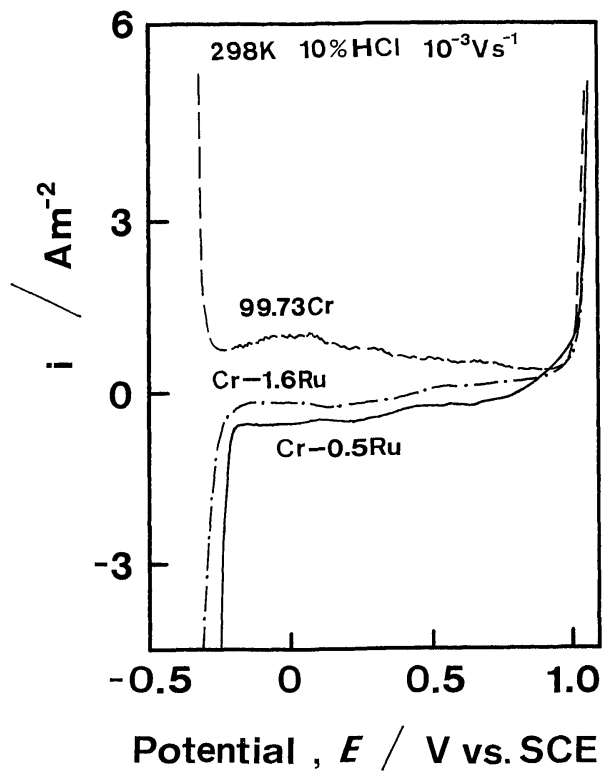

Fig. 11 Polarization curves of $\mathrm{Cr}$ and $\mathrm{Cr}-\mathrm{Ru}$ alloys in $\mathrm{HCl}$ solution.

も貴であり，金属 $\mathrm{Cr}$ の不働態化能力を付加するためには $\mathrm{Ru}$ を添加する方が有利であると言える。

次に, $\mathrm{Cr}-0.5 \mathrm{Ru}$ 合金, $\mathrm{Cr}-1.6 \mathrm{Ru}$ 合金拉よび金属 $\mathrm{Cr}$ の アノード分極曲線を Fig. 11 に示す． 0.5\%の Ru 添加に より金属 $\mathrm{Cr}$ の活性溶解の電流ピークは消隇して括り, 不 働態保持電流もきわめて小さい值を示している. Cr-Pd 合 金については Fig. 8 亿示したように吸蔵水素の酸化に伴 ら不働態保持電流の増加が認められたが, $\mathrm{Cr}-\mathrm{Ru}$ 合金で は全くみられない。

$\mathrm{Ru}$ の添加効果をさらに詳細に検討するために， -0.3 $\mathrm{V}$ と $0.1 \mathrm{~V}$ 亿掃引開始電位を変化させて金属 $\mathrm{Ru}$ のアノー ド分極曲線を測定し，得られた結果を Fig. 12 亿示す．金 属 Ru は金属 Pd と同様にカソード電流が大きく観測され る.このため $\mathrm{Cr}-\mathrm{Ru}$ 合金のカソード電流も金属 $\mathrm{Cr}$ に比べ るとはるかに大きく, 活性溶解の電流ピークはすべて消隇 してしまう。また，金属 Ruは金属 $\mathrm{Pd}$ と異なり卑な電位 から掃引を開始し，カソード反応を十分に生じさせても水 素の吸蔵を生じないため Fig. 12に示すように $0 \mathrm{~V}$ 以上の 電位領域に扮いて水素の酸化によるアノード電流の増加は 見られない，そして，金属Ruは，Fig. 7 に示した金属 $\mathrm{Pd}$ の分極曲線に見られるよらな $0.5 \mathrm{~V}$ 付近からのアノー ド溶解反応も生じない。このため金属 $\mathrm{Ru}$ は $1.0 \mathrm{~V}$ 以上の 貴な領域まで注とんど溶解しない。

金属 Ru は, Fig. 12 亿示すように引続き貴な電位領域 から卑な方向へと分極させると， $0.3,1.0 \mathrm{~V}$ 附近にいくつ かのカソード電流ピークが観測される.これは， Ru の酸 化還元反応が可逆的に 2 段階で生じているためと考兄ら れる。

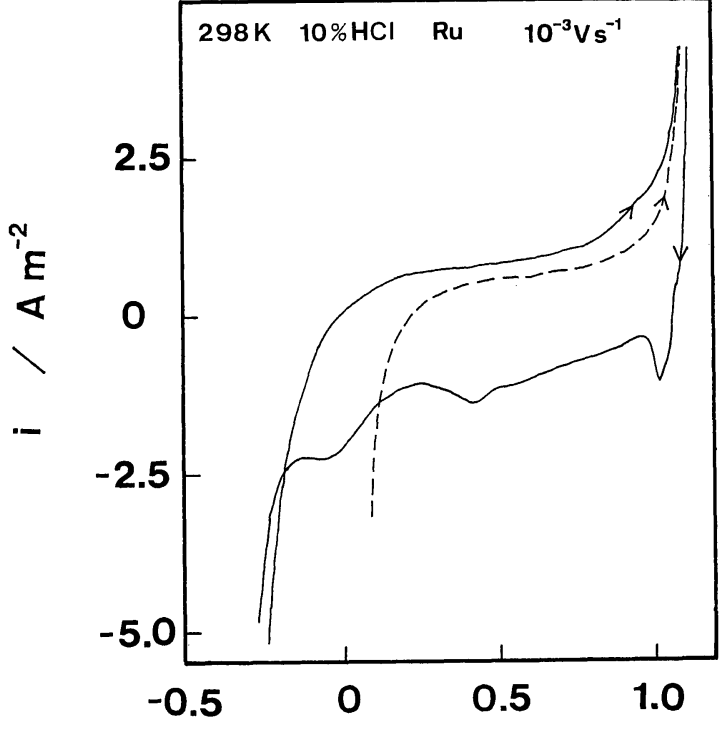

\section{Potential, E / V vs.SCE}

Fig. 12 Polarization curves of $\mathrm{Ru}$ in $\mathrm{HCl}$ solution. The starting potentials for the sweep were changed from $0.1 \mathrm{~V}(\cdots)$ ) to $-0.3 \mathrm{~V}(-)$.

\section{Cr-Mo 合金の腐食挙動}

$10 \%$ 塩酸中に打ける $5 \%$ 打よび $10 \%$ Mo 添加合金の腐食 速度の温度依存性を Fig. 13 亿示す. $5 \% \mathrm{Mo}$ 添加合金は 金属 $\mathrm{Cr}$ に比較すると耐食性に優れ，高温にも耐えられる

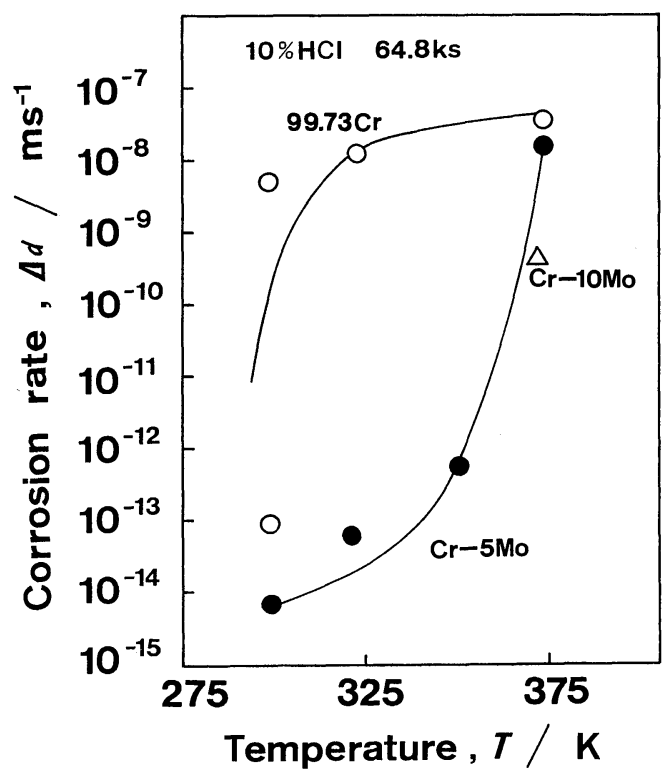

Fig. 13 Effect of temperature on the corrosion rates of $\mathrm{Cr}-\mathrm{Mo}$ alloys immersed in $\mathrm{HCl}$ solution. 
ようになる。しかし， $350 \mathrm{~K}$ 以上になると $10 \% \mathrm{Mo}$ 添加合 金でも激しい腐食を生じる.Cr-Mo 合金は Mo の固溶量 が高く $10 \%$ 添加しても単一固溶合金を得ることが出来, 腐食形態としても均一な全面腐食を呈し，選択的な腐食を 生じない点では有望な添加元素である。しかしながら, $\mathrm{Pd}, \mathrm{Ru}$ 等の貴金属注どの耐食性改善効果は期待できない。

ここでは図示していないが，Moの添加効果をさらに調 べるためにアノード捛よびカソード分極曲線を測定した。 分極測定の結果から $\mathrm{Cr}^{3+}$ または $\mathrm{Cr}^{2+}$ としての活性溶解 ピークを減少させる作用はあるが，Mo 合金では Pd や $\mathrm{Ru}$ 合金汪ど大きな抑制効果はみられない。ただし， Pd 添加合金でみられたような不働態領域に括ける吸藏水素の 酸化に伴う不働態保持電流の上昇を生じることはない。

\section{N. 結論}

塩酸中での $\mathrm{Cr}-\mathrm{Pd}, \mathrm{Cr}-\mathrm{Ru}$ 合金拉よび Cr-Mo 合金の腐食 挙動を調査解析し以下の結論を得た.

（1）Crは Ti に比べると，塩酸中に掓る不働態皮膜の 溶出量が少なく, 不働態皮膜自体は十分安定である.

(2) $\mathrm{Cr}$ は極微量の Pd あるいは Ru の添加により, 活性 溶解を生じることなく塩酸中でる安定に不働態化する.

（3） Pd の効果は $\mathrm{Cr}$ のカソード電流を増加させ，電位 を貴に移行させるものであり，不働態皮膜自体の改質には 寄与していない。

（4）金属 $\mathrm{Cr}$ の耐食性向上のための $\mathrm{Ru}$ 添加は $\mathrm{Pd}$ 以上
の添加効果があり, 高温で10\%以上の高濃度の塩酸中に 特いても0.5\%以上の添加で十分な耐食性を維持する.

（5）合金添加元素として Ru は Pd 同様，金属 $\mathrm{Cr}$ に対 しカソード復極剤として作用するが，ほかに不働態保持電 流を低減させる効果がある.

（6） Mo 添加合金も金属 $\mathrm{Cr}$ の耐塩酸性の向上飞寄与寸 るが，Ru 飞比較するとその効果は小さい.

\section{文献}

(1) H. P. Martinz, R. Eck, J. Eiter, M. Kato and T. Sakaki: Werkst. Korros., 40(1989), 715.

(2) R. Eck, H. P. Martinz, T. Sakaki and M. Kato: Materials Science and Engineering, A120(1989), 307.

（3）清水要樹, 榊 孝, 加藤雅敏 : 東ソ一研究報告, 33(1989), 148.

（4）大森正信, 賀屋 章, 原田泰典, 吉田総仁, 伊藤 操 : 日本金属学会誌, 52 (1988), 223.

（5）原田泰典, 大森正信, 吉田総仁, 伊藤 操：日本金 属学会誌, 53(1989), 201.

（6）原田泰典, 大森正信, 吉田総仁, 伊藤 操：日本金 属学会誌, 53(1989), 921.

（7）吉葉正行, 和田 浩, 榊 孝, 加藤雅敏 : 日本金 属学会誌, 54(1990), 794.

（8）加藤雅敏, 棉 孝：日本金属学会誌，55(1991), 564.

（9）加藤雅敏, 榊 孝：日本金属学会誌，55(1991), 1108.

（10）加藤雅敏, 榊孝：腐食防食討論会講演集, (1989), 179.

（11）加藤雅敏, 榊 孝：日本金属学会誌, 56(1992), 67. 